\title{
Determination of Vitamin $C$ in Various Colours of Bell Pepper (Capsicum annuum L.) by Titration Method
}

\author{
Nerdy Nerdy* \\ Department of Pharmacy, Academy of Pharmacy Yayasan Tenaga Pembangunan Arjuna, Pintubosi, \\ Laguboti, Toba Samosir, Sumatera Utara, 22381, Indonesia \\ * Corresponding author \\ E-mail: nerdy190690@gmail.com
}

DOI: 10.20961/alchemy.14.1.15738.164-177

Received 8 November 2017, Accepted 16 January 2018, Published 1 March 2018

\begin{abstract}
Vitamin $\mathrm{C}$ is needed by the human body to improve the immune system and can be obtained from the bell pepper. Bell pepper has a different color according to the maturity stages, ranging from green, yellow, orange, and red. Differences in color also make possible differences in vitamin C content. The purpose of this study was to determine vitamin $\mathrm{C}$ levels in various colors of bell fruit. Measurement of vitamin $\mathrm{C}$ was done by the titration method with metaphosphoric acid as the vitamin $\mathrm{C}$ oxidizing inhibitor and 2,6-dichloroindophenol as the standard solution. The samples used were green bell pepper, yellow bell pepper, orange bell pepper, and red bell pepper taken from Gundaling, Berastagi, Karo, Sumatera Utara, 22152, Indonesia. The results show that vitamin $\mathrm{C}$ levels in various colors of bell pepper, for green bell pepper $16.52 \mathrm{mg}$ vitamin C per $100 \mathrm{~g}$ green bell pepper; yellow bell pepper $159.61 \mathrm{mg}$ vitamin C per $100 \mathrm{~g}$ yellow bell pepper; orange bell pepper $121.38 \mathrm{mg}$ vitamin $\mathrm{C}$ per $100 \mathrm{~g}$ orange bell pepper; red bell pepper $81.19 \mathrm{mg}$ vitamin $\mathrm{C}$ per $100 \mathrm{~g}$ red bell pepper. These results indicate that different stages of bell pepper maturity have different vitamin $\mathrm{C}$ levels.
\end{abstract}

Keywords: vitamin C, various colors, bell Pepper, Capsicum annuum, titration

\section{INTRODUCTION}

Indonesia is one tropical country that has a wealth of vegetables and fruits. Bell pepper is one of the many vegetable commodities cultivated in Indonesia. Bell pepper comes from Central and South America where many varieties of bell pepper have been cultivated (Padrón et al., 2015). Bell pepper contains nutrients such as carbohydrates, proteins, fats, minerals (potassium, calcium, phosphorus, and iron), and vitamins (vitamin A, vitamin B, and vitamin C) (Nadeem et al., 2011). Vitamin C is also known as ascorbic acid that can be found in nature almost in all plants, especially fresh vegetables, and fresh fruits, so called fresh food vitamins (Singh and Kumari, 2015). 
Vitamin $\mathrm{C}$ is known as an important compound in the body, such as collagen production, fat carrier, cholesterol regulator, and immune boosters (Pacier and Martirosyan, 2015). Bell pepper is one of the vegetables rich in vitamin C. Vitamin C different levels may be due to varieties, growth conditions (temperature, soil, fertilizer), harvesting, post-harvest (storage, and processing) and maturity stages (Lee and Kader, 2000; Njoku et al., 2011). Figure 1 shows various colors of bell pepper, depending on its maturity stages.

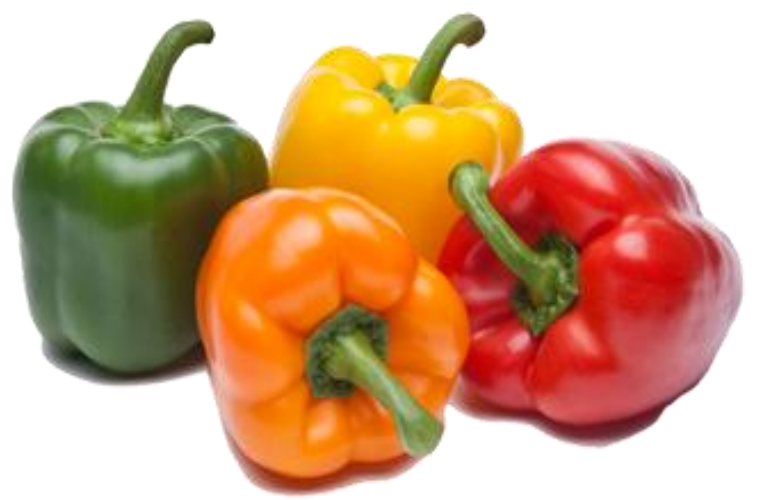

Figure 1. Various colors of bell pepper, depending on its maturity stages

There are several methods in determining vitamin $\mathrm{C}$ levels, namely: iodimetry titration method (Bekele and Geleta, 2015; Tareen et al., 2015), 2,6-dichloroindophenol titration method (Shrestha et al., 2016), voltammetry method (Pisoschi et al., 2008; Pisoschi et al., 2011), spectrophotometer method (Al Majidi and Al Quburi, 2016), and chromatography method (Gazdik et al., 2008; Trani et al., 2012). Spectrophotometric methods and chromatographic methods require an instrument in the measurement of vitamin C. The simplest and fastest method for vitamin $\mathrm{C}$ analysis is the titration method which can also give similar analytical results to spectrophotometric method and chromatography method (Ullah et al., 2012).

Foodstuffs were complex matrix that contains many reducing agents other than vitamin $\mathrm{C}$. The iodimetry titration method uses an iodine solution as the standard solution and not effective for measuring vitamin $\mathrm{C}$ levels in foodstuffs, because iodine not selective to vitamin $\mathrm{C}$ and oxidize all reducing agents besides of vitamin $\mathrm{C}$. The 2,6dichloroindophenol titration method use 2,6-dichloroindophenol solution as the standard solution and most widely used for determining vitamin $\mathrm{C}$ levels in foodstuffs, because 2,6dichloroindophenol selective to vitamin $\mathrm{C}$ (only oxidize vitamin $\mathrm{C}$ ) and not oxidize others reducing agents (Tantray et al., 2017). 
The different maturity stages will affect the vitamin $\mathrm{C}$ content contained in fruits and vegetables (Moneruzzaman et al., 2008). Bell pepper has a different color according to the stages of maturity, ranging from green, yellow, orange, and red (green indicates immature, yellow and orange indicate half mature, and red indicates mature). Determination of vitamin $\mathrm{C}$ in various colors of bell pepper growth in Indonesia by 2,6dichloroindophenol titration method has not been reported previously. The reaction between vitamin $\mathrm{C}$ with 2,6-dichloroindophenol can be seen in Figure 2.

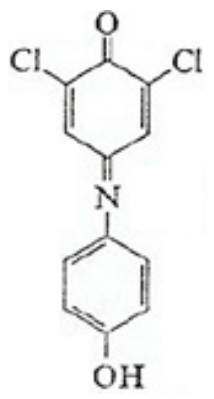

2,6-Dichloroindophenol

(Base Condition - Blue)

(Acid Condition - Pink)

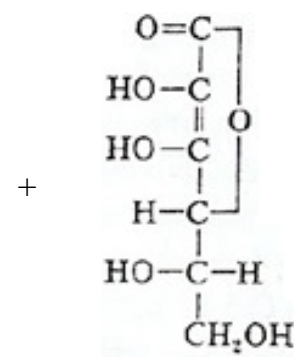

Ascorbic Acid<smiles>Oc1ccc(Nc2cc(Cl)c(O)c(Cl)c2)cc1</smiles>

Reduced

2,6-Dichloroindophenol

(Colorless)

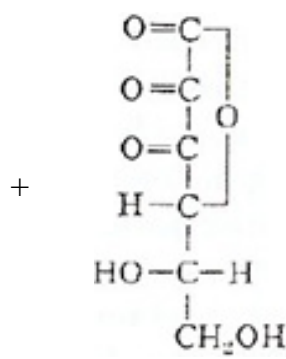

Oxidized

Ascorbic Acid

Figure 2. Reaction between vitamin $\mathrm{C}$ with 2,6-dichloroindophenol

The authors are interested to determine the levels of vitamin $C$ from bell pepper different colors according to the stages of maturity, wherein this research, the researcher used four different samples: green bell pepper, yellow bell pepper, orange bell pepper, and red bell pepper. The method of determining vitamin $\mathrm{C}$ levels used in this study was done by the titration method using 2,6-dichloroindophenol as the standard solution and metaphosphoric acid as the vitamin C oxidizing inhibitor (Najwa and Azrina, 2017). The objectives of this research are to know the difference of vitamin $\mathrm{C}$ levels contains in green bell pepper, yellow bell pepper, orange bell pepper, and red bell pepper red.

\section{METHODS}

This research is descriptive research. This study aims to determine the vitamin C levels in various colors of bell pepper, depending on the maturity stages of bell pepper. The sample used in this study is the bell pepper growth in Gundaling, Berastagi, Karo, Sumatera Utara, 22152, Indonesia. Average Altitude 1,375 meters above sea level, Temperature $16{ }^{\circ} \mathrm{C}$ to $26{ }^{\circ} \mathrm{C}$, Relative Humidity $60 \%$ to $100 \%$, Rainfall $2100 \mathrm{~mm}$ to 3200 
mm, Soil pH 5 to 6, Atmospheric Pressure $1009 \mathrm{HPa}$ to $1015 \mathrm{HPa}$, Wind Speed $4 \mathrm{KM} / \mathrm{h}$ to $11 \mathrm{KM} / \mathrm{h}$.

Materials used in this research are 2,6-dichloroindophenol (Merck), methanol (Merck), metaphosphoric acid (Merck), sodium bicarbonate (Merck), vitamin C (Merck), and distilled water (Brataco). Tools used in this research are analytical balance (Shimadzu), blender (Philips), volume pipette $5 \mathrm{~mL}, 10 \mathrm{~mL}$ (Iwaki), measuring pipette 5 $\mathrm{mL}, 10 \mathrm{~mL}$ (Iwaki), burette $10 \mathrm{~mL}, 25 \mathrm{~mL}, 50 \mathrm{~mL}$ (Iwaki), erlenmeyer $25 \mathrm{~mL}, 50 \mathrm{~mL}$ (Iwaki), beaker glass $50 \mathrm{~mL}, 100 \mathrm{~mL}$ (Iwaki), volumetric flask $50 \mathrm{~mL}, 100 \mathrm{~mL}$ (Iwaki), measuring glass $5 \mathrm{~mL}, 10 \mathrm{~mL}, 25 \mathrm{~mL}, 50 \mathrm{~mL}$ (Iwaki), statif and clamp, dropping pipette, and funnel.

\section{Preparation of Sodium Bicarbonate Solution $0.84 \%(\mathrm{~m} / \mathrm{v})$}

$0.84 \mathrm{~g}$ of sodium bicarbonate was weighed, put into a $100 \mathrm{~mL}$ volumetric flask, added $50 \mathrm{~mL}$ of distilled water, shaken until dissolved, added distilled water to the marking line, and homogenized the mixture.

\section{Preparation of Metaphosphoric Acid Solution 3\% ( $\mathrm{m} / \mathrm{v})$}

$3 \mathrm{~g}$ of metaphosphoric acid was weighed, put into a $100 \mathrm{~mL}$ volumetric flask, added $50 \mathrm{~mL}$ of distilled water, shaken until dissolved, added distilled water to the marking line, and homogenized the mixture.

\section{Preparation of 2,6-Dichloroindophenol Solution $0.025 \%(\mathrm{~m} / \mathrm{v})$}

$25 \mathrm{mg}$ 2,6-dichloroindophenol was weighed, put into a $100 \mathrm{~mL}$ volumetric flask, added $25 \mathrm{~mL}$ of sodium bicarbonate solution $0.84 \%$ ( ${ }^{\text {mass }} /$ volume), shaken until dissolved, added distilled water to the marking line, and homogenized the mixture.

\section{Determination of Equality of Vitamin C to 2,6-Dichloroindophenol Solution}

$50 \mathrm{mg}$ of vitamin $\mathrm{C}$ was weighed, put into a $100 \mathrm{~mL}$ volumetric flask, added $50 \mathrm{~mL}$ of metaphosphoric acid solution, shaken until dissolved, added the metaphosphoric acid solution to the marking line, and homogenized the mixture. $10 \mathrm{~mL}$ of vitamin $\mathrm{C}$ solution was pipetted, put into erlenmeyer, added $5 \mathrm{~mL}$ metaphosphoric acid solution, titrated with the 2,6-dichloroindophenol solution until the steady pink color. Performed titration of the sample as much as 6 times replications and done a blank titration. According to Hussain et al (2016), the equality was calculated by the formula (equation 1): 


$$
\mathrm{E}=\frac{\mathrm{v}_{\mathrm{A}} \times \mathrm{w}_{\mathrm{VC}} \times \mathrm{P}_{\mathrm{VC}}}{\mathrm{v}_{\mathrm{VF}} \times\left(\mathrm{v}_{\mathrm{VCT}}-\mathrm{v}_{\mathrm{BT}}\right)}
$$

Explanation:

$$
\begin{array}{ll}
\mathrm{E} & =\text { equality }(\mathrm{mg} / \mathrm{mL}) \\
\mathrm{V}_{\mathrm{A}} & =\text { volume of aliquot }(\mathrm{mL}) \\
\mathrm{W}_{\mathrm{VC}} & =\text { weight of vitamin } \mathrm{C}(\mathrm{mg}) \\
\mathrm{P}_{\mathrm{VC}} & =\text { purity of vitamin } \mathrm{C}(\%) \\
\mathrm{V}_{\mathrm{VF}} & =\text { volume of volumetric flask }(\mathrm{mL}) \\
\mathrm{V}_{\mathrm{VCT}} & =\text { volume of vitamin } \mathrm{C} \text { titration }(\mathrm{mL}) \\
\mathrm{V}_{\mathrm{BT}} & =\text { volume of blank titration }(\mathrm{mL})
\end{array}
$$

\section{Determination of Vitamin C Levels in Bell Pepper}

Samples consisting of green bell pepper, yellow bell pepper, orange bell pepper, and red bell pepper were washed, carefully weighed $200 \mathrm{~g}$ of each sample, and blended until smooth. $20 \mathrm{~g}$ of blended sample was weighed, put into a $100 \mathrm{~mL}$ volumetric flask, added $50 \mathrm{~mL}$ of metaphosphoric acid solution, mixed well, and added the metaphosphoric acid solution to the marking line, and homogenized the mixture. $10 \mathrm{~mL}$ of sample mixture was pipetted, put into erlenmeyer, added $5 \mathrm{~mL}$ metaphosphoric acid solution, titrated with the 2,6-dichloroindophenol solution until the steady pink color. Performed titration of the sample as much as 6 times replications and done a blank titration. According to Horwitz (2003), vitamin C levels were calculated by the formula (equation 2):

$$
\mathrm{L}=\frac{\left(\mathrm{v}_{\mathrm{ST}}-\mathrm{V}_{\mathrm{BT}}\right) \times \mathrm{E} \times \mathrm{v}_{\mathrm{VF}} \times 100}{\mathrm{v}_{\mathrm{A}} \times \mathrm{W}_{\mathrm{S}}}
$$

Explanation:

$$
\begin{array}{ll}
\mathrm{L} & =\text { levels of vitamin } \mathrm{C}(\mathrm{mg} / 100 \mathrm{~g}) \\
\mathrm{V}_{\mathrm{ST}} & =\text { volume of sample titration }(\mathrm{mL}) \\
\mathrm{V}_{\mathrm{BT}} & =\text { volume of blank titration }(\mathrm{mL}) \\
\mathrm{E} & =\text { equality }(\mathrm{mg} / \mathrm{mL}) \\
\mathrm{V}_{\mathrm{VF}} & =\text { volume of volumetric flask }(\mathrm{mL}) \\
\mathrm{V}_{\mathrm{A}} & =\text { volume of aliquot }(\mathrm{mL}) \\
\mathrm{W}_{\mathrm{S}} & =\text { weight of sample }(\mathrm{g})
\end{array}
$$

\section{Accuracy Test and Precision Test for 2,6-Dichloroindophenol Titration Method}

To prove that vitamin $\mathrm{C}$ in various colors of bell pepper determined by the titration method has been valid, validation of 2,6-dichloroindophenol titration method with accuracy and precision parameters was performed. Accuracy is done by the standard 
addition method. Vitamin $\mathrm{C}$ is added in the range of $50 \%, 100 \%$, and $150 \%$ of the vitamin $\mathrm{C}$ content contained in each sample. Performed titration of the sample as much as 6 times replications and done a blank titration. According to Harmita (2004), the recovery percentage was calculated by the formula (equation 3 )

$$
\mathrm{R}=\frac{\mathrm{A}-\mathrm{B}}{\mathrm{C}}
$$

Explanation:

$\mathrm{R} \quad=$ recovery percentage $(\%)$
A = vitamin $\mathrm{C}$ levels after the addition of standard vitamin $\mathrm{C}(\mathrm{mg})$
$\mathrm{B} \quad=$ vitamin $\mathrm{C}$ levels before the addition of standard vitamin $\mathrm{C}(\mathrm{mg})$
$\mathrm{C} \quad=$ vitamin $\mathrm{C}$ levels added $(\mathrm{mg})$

\section{DISCUSSIONS}

\section{Determination of Equality of Vitamin C to 2,6-Dichloroindophenol Solution}

The initial stage of the study begins with the determination of equivalence of vitamin $\mathrm{C}$ to the 2,6-dichloroindophenol solution as the standard solution. The equality (E) $(\mathrm{mg} / \mathrm{mL})$ was calculated based on weighing data and titration data. The results of the determination of equality of vitamin $\mathrm{C}$ to the 2,6-dichloroindophenol solution can be seen in Table 1.

Table 1. Results of the determination of equality of vitamin $C$ to 2,6-dichloroindophenol solution

\begin{tabular}{ccccc}
\hline Number & $\begin{array}{c}\mathbf{W}_{\mathbf{V C}} \\
(\mathbf{m g})\end{array}$ & $\begin{array}{c}\mathbf{V}_{\mathbf{V C T}} \\
(\mathbf{m L})\end{array}$ & $\begin{array}{c}\mathbf{V}_{\mathbf{B T}} \\
(\mathbf{m L})\end{array}$ & $\begin{array}{c}\mathbf{E} \\
(\mathbf{m g} / \mathbf{m L})\end{array}$ \\
\hline $\mathbf{1 .}$ & 50.4 & 37.35 & 0.05 & 0.1351 \\
$\mathbf{2 .}$ & 50.1 & 37.15 & 0.05 & 0.1350 \\
$\mathbf{3 .}$ & 50.6 & 37.50 & 0.05 & 0.1350 \\
\hline $\boldsymbol{\Sigma}$ & $\mathbf{1 5 1 . 1}$ & $\mathbf{1 1 2 . 0 0}$ & $\mathbf{0 . 1 5}$ & $\mathbf{0 . 4 0 5 1}$ \\
\hline Average & $\mathbf{5 0 . 4}$ & $\mathbf{3 7 . 3 3}$ & $\mathbf{0 . 0 5}$ & $\mathbf{0 . 1 3 5 0}$ \\
\hline
\end{tabular}

The scale of burette used in determination of equality of vitamin $C$ to 2,6dichloroindophenol solution was $50 \mathrm{~mL}$. Determination of equality of vitamin $\mathrm{C}$ to $2,6-$ dichloroindophenol solution obtained results that $0.1350 \mathrm{mg}$ of vitamin $\mathrm{C}$ is equivalent to 1 $\mathrm{mL}$ of 2,6-dichloroindophenol solution $0.025 \%(\mathrm{~m} / \mathrm{v})$. This equality results similar to the theoretical equality value that $0.1350 \mathrm{mg}$ of vitamin $\mathrm{C}(0,7666 \mu \mathrm{mole})$ is equivalent to 1 $\mathrm{mL}$ of 2,6-dichloroindophenol solution $0.025 \%(\mathrm{~m} / \mathrm{v})(0,7666 \mu$ mole $)$. 


\section{Determination of Vitamin C Levels in Bell Pepper}

Vitamin C titrations should be performed quickly because of many factors that lead to oxidation of vitamin $\mathrm{C}$ for example in sample preparation or grinding. The vitamin $\mathrm{C}$ oxidizing inhibitor used for the titration method with the 2,6-dichloroindophenol solution as the standard solution is metaphosphoric acid, acetic acid, trichloroacetic acid, and oxalic acid solutions to prevent oxidation of vitamin $\mathrm{C}$ contained in the sample before being oxidized by the 2,6-dichloroindophenol solution. The use of the above acids is also useful for reducing the oxidation of vitamin $\mathrm{C}$ by oxidative enzymes present in the plant tissue. The acidic atmosphere of the solution will give more accurate results than the neutral atmosphere or the alkaline atmosphere (Counsell and Hornig, 1981).

The principle of analysis of vitamin $\mathrm{C}$ content by 2,6-dichloroindophenol titration method is to determine the vitamin $\mathrm{C}$ levels based on 2,6-dichloroindophenol reduction reaction and vitamin $\mathrm{C}$ oxidation reaction in acid solution. Ascorbic acid reduces 2,6dichloroindophenol to the colorless solution. The titration end point is marked by the change of color to pink under acidic conditions (Ruvini et al., 2017). Data of vitamin C levels in various colors of bell pepper can be seen in Table 2. Graph of vitamin C levels in various colors of bell pepper can be seen in Figure 3.

Table 2. Data of vitamin C levels in various colors of bell pepper

\begin{tabular}{|c|c|c|c|c|}
\hline \multirow{2}{*}{ Number } & \multicolumn{4}{|c|}{$\begin{array}{l}\text { Vitamin C Levels in Various Colors of Bell Pepper } \\
(\mathrm{mg} / \mathbf{1 0 0} \mathrm{g})\end{array}$} \\
\hline & $\begin{array}{c}\text { Green } \\
\text { Bell Pepper }\end{array}$ & $\begin{array}{c}\text { Yellow } \\
\text { Bell Pepper }\end{array}$ & $\begin{array}{c}\text { Orange } \\
\text { Bell Pepper }\end{array}$ & $\begin{array}{c}\text { Red } \\
\text { Bell Pepper }\end{array}$ \\
\hline 1 & 16.56 & 159.92 & 121.83 & 81.33 \\
\hline 2 & 16.49 & 158.99 & 121.05 & 81.02 \\
\hline 3 & 16.57 & 160.33 & 120.66 & 80.88 \\
\hline 4 & 16.69 & 159.66 & 121.31 & 81.77 \\
\hline 5 & 16.44 & 159.12 & 121.98 & 81.47 \\
\hline 6 & 16.37 & 159.64 & 121.45 & 80.67 \\
\hline Minimum & 16.37 & 158.99 & 120.66 & 80.67 \\
\hline Maximum & 16.69 & 160.33 & 121.98 & 81.77 \\
\hline Average & 16.52 & 159.61 & 121.38 & 81.19 \\
\hline Standard Deviation & 0.11 & 0.50 & 0.49 & 0.41 \\
\hline
\end{tabular}

Previous research on tomato showed that immature tomato contains highest vitamin

$\mathrm{C}$ level, half mature tomato contains lower vitamin $\mathrm{C}$ level than immature tomato, and mature tomato contains a higher vitamin $\mathrm{C}$ level than half mature tomato. In previous research, the vitamin $\mathrm{C}$ level in the tomato sample from immature to mature was decreased and then increased (Moneruzzaman et al., 2008). The novelty of this research was in the 
bell pepper sample used in this research not been analyzed yet by the previous researcher. The vitamin $\mathrm{C}$ level in bell pepper has a different trend with the tomato sample, that immature bell pepper (green bell pepper) contains lowest vitamin $\mathrm{C}$ level, increased in yellow bell pepper, decreased in orange bell pepper, and decreased in red bell pepper.

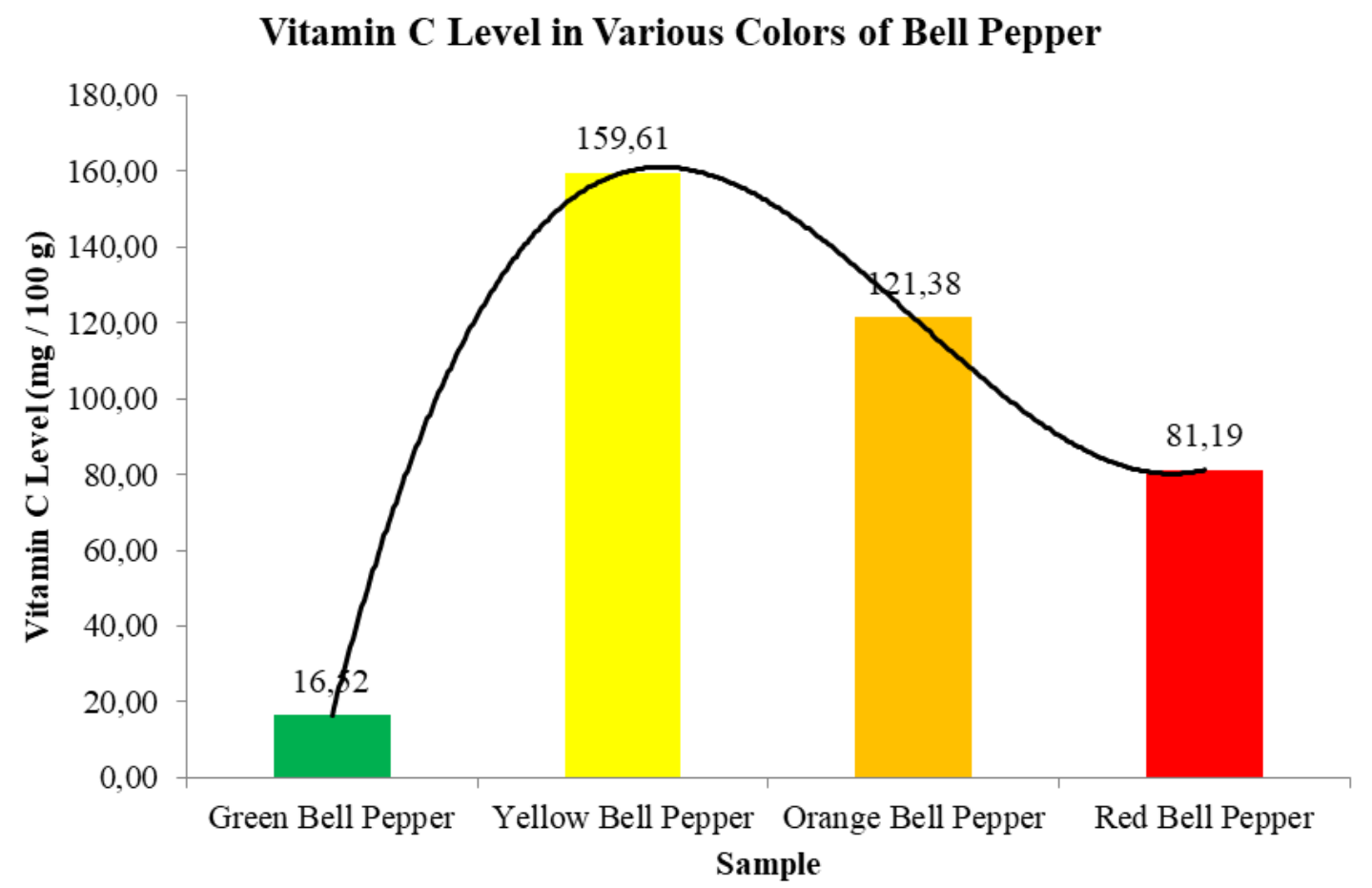

Figure 3. Graph of vitamin C levels in various colors of bell pepper

Determination of vitamin $\mathrm{C}$ levels in bell pepper results shows that the highest vitamin $\mathrm{C}$ content in yellow bell pepper and the lowest vitamin $\mathrm{C}$ content in a green bell pepper. Colors in fruits and vegetables are grouped into four major groups, namely: chlorophyll, anthocyanin, flavonoids, and carotenoids. The color change is also one of the most prominent changes in the fruit maturity process. The color change in the fruits is a synthesis process of a particular pigment and is one of the indicators of chemical change (Muhammad et al., 2014). The value of vitamin C levels is done by analysis of vitamin C level variance in green bell pepper, vitamin $\mathrm{C}$ level in yellow bell pepper, vitamin $\mathrm{C}$ level in orange bell pepper, vitamin $\mathrm{C}$ level in red bell pepper, and vitamin $\mathrm{C}$ level in bell pepper listed in the literature ( $160.00 \mathrm{mg}$ per $100 \mathrm{~g}$ ) to determine the significance of the difference in vitamin $\mathrm{C}$ levels in various colors of bell pepper compared to the vitamin $\mathrm{C}$ level in bell pepper shown in the literature (Mendoza et al., 2015). Data by analysis of variance of vitamin $\mathrm{C}$ levels in various colors of bell pepper can be seen in Table 3. 
Table 3. Data by analysis of variance of vitamin $\mathrm{C}$ levels in various colors of bell pepper

\begin{tabular}{|c|c|c|c|c|}
\hline \multirow{2}{*}{ Sample } & \multicolumn{4}{|c|}{$\begin{array}{l}\text { Vitamin C Levels in Various Colors of Bell Paper } \\
\qquad(\mathrm{mg} / 100 \mathrm{~g})\end{array}$} \\
\hline & Subset 1 & Subset 2 & Subset 3 & Subset 4 \\
\hline $\begin{array}{l}\text { Green Bell Pepper } \\
\text { Red Bell Pepper }\end{array}$ & $16.52^{\mathrm{A}}$ & $81.19^{\mathrm{B}}$ & & \\
\hline Orange Bell Pepper & & & $121.38^{\mathrm{C}}$ & \\
\hline $\begin{array}{l}\text { Yellow Bell Pepper } \\
\text { Literature }\end{array}$ & & & & $\begin{array}{l}159.61^{\mathrm{D}} \\
160.00^{\mathrm{D}}\end{array}$ \\
\hline
\end{tabular}

$(\mathrm{A}, \mathrm{B}, \mathrm{C}$, and D) : Different letters among the groups indicate statistically significant differences $(\mathrm{P}<0.05)$; Same letters among the groups indicate not statistically significant differences $(\mathrm{P}>0.05)$

The data of the statistical test show that there are significant differences between different bell pepper colors. Vitamin $\mathrm{C}$ level in yellow bell pepper was not significantly different from the vitamin $\mathrm{C}$ level in the bell pepper stated in the literature. Vitamin $\mathrm{C}$ levels in green bell pepper, orange bell pepper, and red bell pepper were significantly different to the vitamin $\mathrm{C}$ level in the bell pepper listed in the literature. Vitamin $\mathrm{C}$ different levels may be due to varieties, growth conditions (climate and soil), harvesting conditions (time), post harvest conditions (storage and processing) and maturity stages (immature or mature) (Mateos et al., 2013; Zhigila et al., 2014).

After the harvest of fruits and vegetables, then a number of vitamins can be lost during the storage stage, depending on temperature, exposure to air and sun, and storage time. The higher the temperature, the longer exposed to air and sun, the longer it is stored, the more vitamin $\mathrm{C}$ is lost (Ibrahim, 2016). Changes in physical properties and chemical properties in fresh fruits and vegetables common during maturation are changes in colors and acid levels (Tosun et al., 2008). The longer the fruits and vegetables are stored in the open, the vitamin $\mathrm{C}$ levels will decrease as a result of the oxidation process. So that the titration process during testing should be done quickly to prevent the oxidation of vitamin $\mathrm{C}$ in order to provide more accurate results of vitamin $\mathrm{C}$ (Bieniasz et al., 2017). Factors that also affect the analysis of vitamin $\mathrm{C}$ by 2,6-dichloroindophenol titration method are varieties, temperature, light intensity, metal content, and ascorbate oxidase enzyme. The higher the temperature, the higher the intensity of light, the higher the metal content, and the higher the activity of the ascorbate oxidase enzyme in the analysis process the faster the vitamin $\mathrm{C}$ damage due to the rapid oxidation that interferes the determination of vitamin C levels (Lee and Kader, 2000; Njoku et al., 2011; Oyetade et al., 2012; Méndez and Arancibia, 2015; El Ishaq and Obirinakem, 2015). 
The vitamin $\mathrm{C}$ level in green bell pepper obtained from our research was lower than the vitamin $\mathrm{C}$ level in green bell pepper obtained from previous research, that the vitamin C level in green bell pepper was 27,62 mg / 100 g green bell pepper (Patrick et al., 2016). This may be due to differences of plant varieties, and / or different soil condition, and/or different climatic condition (Djoković et al., 2011). The bell pepper sample used in this research has different climate condition with the bell pepper sample reported in previous research.

The bell pepper used as sample in this research was growth in Berastagi, Karo, Sumatera Utara, 22152, Indonesia, with Average Altitude 1,375 meters above sea level, Temperature $16{ }^{\circ} \mathrm{C}$ to $26{ }^{\circ} \mathrm{C}$, Relative Humidity $60 \%$ to $100 \%$, Rainfall $2100 \mathrm{~mm}$ to 3200 $\mathrm{mm}$; while bell pepper used as sample in previous research was growth in Ugbokolo, Okpokwu, Benue State, 973, Nigeria, with Average Altitude 175 meters above sea level, Temperature $29{ }^{\circ} \mathrm{C}$ to $34{ }^{\circ} \mathrm{C}$, Relative Humidity $40 \%$ to $100 \%$, Rainfall $100 \mathrm{~mm}$ to 200 $\mathrm{mm}$. The higher altitude of certain place will the cause decrease in temperature, increase in relative humidity, and an increase in rainfall. The higher rainfall will increase the soil moisture, increase water uptake by the plant, but decrease the chemical compound quality due to the high water content in the plant (Pessarakli, 2011). Differences in climatic condition may be one of the causes of differences in vitamin $\mathrm{C}$ levels between this research results to the previous research results. However, the differences may also due to another factor, such as: plant varieties and soil condition.

\section{Accuracy Test and Precision Test for 2,6-Dichloroindophenol Titration Method}

To prove that vitamin $\mathrm{C}$ in various colors of bell pepper determined by the titration method has been valid then validated the 2,6-dichloroindophenol titration method with accuracy parameter and precision parameter. Table 4 showed the data of accuracy test and precision test in various colors of bell pepper by 2,6-dichloroindophenol titration method.

Accuracy test results in 2,6-dichloroindophenol titration method showed that recovery percentage was $97.30 \%$ for green bell pepper, $101.93 \%$ for yellow bell pepper, $100.23 \%$ for orange bell pepper, and $98.67 \%$ for red bell pepper. Precision test results in 2,6-dichloroindophenol titration method showed that the relative standard deviation was $1.30 \%$ for green bell pepper, $1.73 \%$ for yellow bell pepper, $1.37 \%$ for orange bell pepper, and $1.66 \%$ for red bell pepper. The value obtained for the accuracy test meets the specified requirements, which the recovery percentage is within the range of 95\%-105\% (Garcia et al., 2011). The value obtained for precision test meets the specified requirements, which 
the relative standard deviation is not more than 5\% (Huber, 2007). These results indicate that the method of analysis by 2,6-dichloroindophenol titration method for the determination of vitamin $\mathrm{C}$ levels in various colors of bell pepper has good accuracy and precision.

Table 4. Data of accuracy test and precision test in various colors of bell pepper by 2,6dichloroindophenol titration method

\begin{tabular}{cccccc}
\hline \multirow{2}{*}{ Number } & \multirow{2}{*}{ Range } & \multicolumn{4}{c}{ Recovery Percentage (\%) } \\
\cline { 3 - 6 } & & $\begin{array}{c}\text { Green } \\
\text { Bell Pepper }\end{array}$ & $\begin{array}{c}\text { Yellow } \\
\text { Bell Pepper }\end{array}$ & $\begin{array}{c}\text { Orange } \\
\text { Bell Pepper }\end{array}$ & $\begin{array}{c}\text { Red } \\
\text { Bell Pepper }\end{array}$ \\
\hline $\mathbf{1}$ & 95.54 & 100.26 & 98.22 & 96.58 \\
$\mathbf{2}$ & 96.66 & 99.05 & 98.56 & 97.39 \\
$\mathbf{3}$ & & 95.89 & 100.79 & 98.93 & 96.16 \\
$\mathbf{4}$ & $\mathbf{5 0 \%}$ & 95.77 & 99.33 & 98.82 & 96.22 \\
$\mathbf{5}$ & & 95.95 & 100.44 & 98.75 & 96.92 \\
$\mathbf{6}$ & & 95.45 & 99.87 & 98.32 & 97.23 \\
\hline $\mathbf{7}$ & & 96.88 & 102.44 & 100.33 & 98.88 \\
$\mathbf{8}$ & & 97.03 & 101.32 & 100.88 & 99.05 \\
$\mathbf{9}$ & $\mathbf{1 0 0 \%}$ & 97.81 & 101.92 & 99.78 & 98.23 \\
$\mathbf{1 0}$ & & 96.95 & 102.21 & 100.65 & 99.02 \\
$\mathbf{1 1}$ & 97.55 & 101.84 & 100.49 & 98.65 \\
$\mathbf{1 2}$ & & 97.47 & 101.39 & 99.87 & 98.47 \\
\hline $\mathbf{1 3}$ & & 98.12 & 104.25 & 102.05 & 100.12 \\
$\mathbf{1 4}$ & & 99.27 & 104.37 & 101.76 & 100.35 \\
$\mathbf{1 5}$ & $\mathbf{1 5 0 \%}$ & 98.69 & 103.32 & 101.29 & 101.02 \\
$\mathbf{1 6}$ & & 98.55 & 103.77 & 101.83 & 100.97 \\
$\mathbf{1 7}$ & & 99.07 & 104.01 & 102.02 & 100.23 \\
$\mathbf{1 8}$ & & 98.76 & 104.21 & 101.64 & 100.49 \\
\hline \multicolumn{7}{r}{ Standard Deviation } & 97.30 & 101.93 & 100.23 & 98.67 \\
\hline Relative Standard & 0.0126 & 0.0176 & 0.0137 & 0.0164 \\
\hline & Deviation & 1.30 & 1.73 & 1.37 & 1.66 \\
\hline
\end{tabular}

\section{CONCLUSIONS}

Vitamin $\mathrm{C}$ levels in various colors of bell pepper can be determined by the titration method with metaphosphoric acid as the vitamin $\mathrm{C}$ oxidizing inhibitor and 2,6dichloroindophenol as the standard solution. The highest level of vitamin $\mathrm{C}$ is found in yellow bell pepper. The lowest level of vitamin $\mathrm{C}$ is found in the green bell pepper. Levels of vitamin $\mathrm{C}$ contained in green bell pepper, yellow bell pepper, orange bell pepper and red bell pepper respectively was $16,52 \mathrm{mg}$ vitamin C per $100 \mathrm{~g}$ green bell pepper, 159,61 mg vitamin $\mathrm{C}$ per $100 \mathrm{~g}$ yellow bell pepper, $121.38 \mathrm{mg}$ vitamin $\mathrm{C}$ per $100 \mathrm{~g}$ orange bell 
pepper, and $81.19 \mathrm{mg}$ vitamin C per $100 \mathrm{~g}$ red bell pepper. Different colors of bell pepper have significantly different vitamin $\mathrm{C}$ content.

\section{ACKNOWLEDGEMENTS}

The authors acknowledge the financial support by Department of Pharmacy, Academy of Pharmacy Yayasan Tenaga Pembangunan Arjuna, Pintubosi, Laguboti, Toba Samosir, Sumatera Utara, 22381, Indonesia.

\section{REFERENCES}

Al Majidi, M.I.H., and Al Qubury, H.Y. 2016. Determination of Vitamin C (Ascorbic Acid) Contents in Various Fruit and Vegetable by UV Spectrophotometry and Titration Methods. Journal of Chemical and Pharmaceutical Sciences 9(4), 29722974.

Bekele, D.A., and Geleta, G.S. 2015. Iodometric Determination of the Ascorbic Acid (Vitamin C) content of some Fruits consumed in Jimma Town Community in Ethiopia. Research Journal of Chemical Sciences 5(1), 60-63.

Bieniasz, M., Dziedzic, E., and Kaczmarczyk, E. 2017. The Effect of Storage and Processing on Vitamin C Content in Japanese Quince Fruit. Folia Horticulturae 29(1), 83-93.

Counsel, J.N. and Hornig, D.H. 1981. Vitamin C. London and New Jersey: Applied Science Publishers.

Djoković, G.A., Pavlović, R., Mladenović, J., and Djurić, M. 2011. Vitamin C Content in Different Types of Lettuce Varieties. Acta Agriculturae Serbica 16(32), 83-89.

El Ishaq, A., and Obirinakem, S. 2015. Effect of Temperature and Storage on Vitamin C Content in Fruits Juice. International Journal of Chemical and Biomolecular Science 1(2), 17-21.

Garcia, P.L., Buffoni, E., Gomes, F.P., and Quero, J.L.V. 2011. Analytical Method Validation, Wide Spectra of Quality Control. Dr. Isin Akyar (Ed.). ISBN: 978-953307-683-6. InTech. Available from: http://www.intechopen.com/books/widespectra-of-quality-control/analytical-method-validation.

Gazdik, Z., Zitka, O., Petrlova, J., Adam, V., Zehnalek, J., Horna, A., Reznicek, V., Beklova, M., and Kizek, R. 2008. Determination of Vitamin C (Ascorbic Acid) Using High Performance Liquid Chromatography Coupled with Electrochemical Detection. Sensors 8(1), 7097-7112.

Harmita. 2004. Method Validation Implementation Guidelines and Calculations. Jakarta, Indonesia: Department of Pharmacy, Faculty of Mathematics and Natural Sciences, University of Indonesia.

Horwitz, W. 2003. Official Methods of Analysis of the Association of Official Analytical Chemists. $17^{\text {th }}$ Edition. Washington: Association of Analytical Chemists. 
Huber, L. 2007. Validation and Qualification in Analytical Laboratories. New York: Interpharm Informa Healthcare.

Hussain, M.I., Hamza, A., and Rashid, M.A. 2014. Estimation of Vitamin C in Carrot Before Cooking and After Cooking. Journal of Food and Nutrition Sciences 4(4), 108-112.

Ibrahim, M.A. 2016. Effect of Different Storage Condition on $\mathrm{pH}$ and Vitamin C Content in Some Selected Fruit Juices (Pineapple, Pawpaw and Watermelon). International Journal of Biochemistry Research \& Review 11(2), 1-5.

Lee, S.K., and Kader, A.A. 2000. Preharvest and Postharvest Factors Influencing Vitamin C Content of Horticultural Crops. Postharvest Biology and Technology 20(1), 207220.

Mateos, R.M., Jiménez, A., Román, P., Romojaro, F., Bacarizo, S., Leterrier, M., Gómez, M., Sevilla, F., del Río, L.A., Corpas, F.J., and Palma, J.M. 2013. Antioxidant Systems from Pepper (Capsicum annuum L.) - Involvement in the Response to Temperature Changes in Ripe Fruits. International Journal of Molecular Sciences 14(1), 9556-9580.

Méndez, R.F., and Arancibia, S.R. 2015. Vitamin C in Health and Disease: Its Role in the Metabolism of Cells and Redox State in the Brain. Frontiers in Physiology 6(1), 397-407.

Mendoza, C.C., Sanchez, E., Marquez, E.M., Arreola, J.P.S., and Cordova, M.A.F. 2015. Bioactive Compounds and Antioxidant Activity in Different Grafted Varieties of Bell Pepper. Antioxidants 4(1), 427-446.

Moneruzzaman, K.M., Hossain, A.B.M.S., Sani, W., and Saifuddin, M. 2008. Effect of Stages of Maturity and Ripening Conditions on the Biochemical Characteristics of Tomato. American Journal of Biochemistry and Biotechnology 4(4), 336-344

Muhammad, I., Ashiru, S., Ibrahim, I.D., Kanoma, A.I., Sani, I., and Garba, S. 2014. Effect of Ripening Stage on Vitamin C Content in Selected Fruits. International Journal of Agriculture, Forestry and Fisheries 2(3), 60-65

Nadeem, M., Anjum, F.M., Khan, M.R., Saeed, M., and Riaz, A. 2011. Antioxidant Potential of Bell Pepper (Capsicum annum L.) - A Review. Pakistan Journal of Food Sciences 21(1-4), 45-51

Najwa, R.F., and Azrina, A. 2017. Comparison of Vitamin C Content in Citrus Fruits by Titration and High Performance Liquid Chromatography (HPLC) Methods. International Food Research Journal 24(2), 726-733.

Njoku, P.C., Ayuk, A.A., Okoye, C.V. 2011. Temperature Effects on Vitamin C Content in Citrus Fruits. Pakistan Journal of Nutrition 10(12), 1168-1169.

Oyetade, O.A., Oyeleke, G.O., Adegoke, B.M., and Akintunde, A.O. 2012. Stability Studies on Ascorbic Acid (Vitamin C) From Different Sources. IOSR Journal of Applied Chemistry 2(4), 20-24.

Padrón, R.A.R., Guedes, J.V.C., Swarowsky, A., Nogueira, C.U., Cerquera, R.R., and Pérez, J.C.D. 2015. Supplemental Irrigation Levels in Bell Pepper under Shade Mesh and in Open Field - Crop Coefficient, Yield, Fruit Quality and Water Productivity. African Journal of Agricultural Research 10(44), 4117-4125. 
Pacier, C., and Martirosyan, D.M. 2015. Vitamin C - Optimal Dosages, Supplementation and Use in Disease Prevention. Functional Foods in Health and Disease 5(3), 89107.

Patrick, A.O., Fabian, U.A., Peace, I.C., and Fred, O.O. 2016. Determination of Variation of Vitamin C Content of Some Fruits and Vegetables Consumed in Ugbokolo After Prolonged Storage. IOSR Journal of Environmental Science, Toxicology and Food Technology 10(7), 17-19.

Pessarakli, M. 2011. Handbook of Plant and Crop Stress. $3^{\text {rd }}$ Edition. New York: CRC Press.

Pisoschi, A.M., Danet, A.F., and Kalinowski, A. 2008. Ascorbic Acid Determination in Commercial Fruit Juice Samples by Cyclic Voltammetry. Journal of Automated Methods and Management in Chemistry 2008(1), 1-8.

Pisoschi, A.M., Pop, A., Negulescu, G.P., and Pisoschi, A. 2011. Determination of Ascorbic Acid Content of Some Fruit Juices and Wine by Voltammetry Performed at Pt and Carbon Paste Electrodes. Molecules 16(1), 1349-1365.

Ruvini, L., Dissanayaka, W.M.M.M.K., Chathuni, J., Rizliya, V., Swarna, W., and Barana, C.J. 2017. Effect of Different Drying Methods on Antioxidant Activity of Star Fruits (Averrhoa carambola L.). Journal of Nutrition and Diet Supplements 1(1), 16

Shrestha, N., Shrestha S., and Bhattarai, A. 2016. Determination of Ascorbic Acid in Different Citrus Fruits of Kathmandu Valley. Journal of Medical and Biological Science Research 2(1), 9-14

Singh, V., and Kumari, M. 2015. Affets of Ascorbic Acid on Health - A Review Article. International Journal of Applied Home Science 2(9\&10), 289-297.

Tantray, A.K., Dar, S.A., Ahmad, S., and Bhat, S.A. 2017. Spectrophotometric and Titrimetric Analysis of Phytoascorbate. Journal of Pharmacognosy and Phytochemistry 6(1), 27-31.

Tareen, H., Ahmed, S., Mengal, F., Masood, Z., Bibi, S., Mengal, R., Shoaib, S., Irum, U., Akbar. S., Mandokhail, F., and Taj, R. 2015. Estimation of Vitamin C Content in Artificially Packed Juices of Two Commercially Attracted Companies in Relation to Their Significance for Human Health. Biological Forum an International Journal 7(2), 682-685.

Tosun, I., Ustun, N.S., and Tekguler, B. 2008. Physical and Chemical Changes during Ripening of Blackberry Fruits. Scientia Agricola 65(1), 87-90.

Trani, M.T.T., Phillips, K.M., and Cotty, M. 2012. Matrix Specific Method Validation for Quantitative Analysis of Vitamin C in Diverse Foods. Journal of Food Composition and Analysis 26(1), 12-25.

Ullah, S., Hussain, A., Ali, J., Khaliqurrehman, and Ullah, A. 2012. A Simple and Rapid HPLC Method for Analysis of Vitamin C in Local Packed Juices of Pakistan. Middle East Journal of Scientific Research 12(8), 1085-1091.

Zhigila, D.A., Rahaman, A.A.A., Kolawole, O.S., and Oladele, F.A. 2014. Fruit Morphology as Taxonomic Features in Five Varieties of Capsicum annuиm L. Solanaceae. Journal of Botany 2014(1), 1-6. 